\title{
Reduced to Bad Sex: Narratives of Violent Women from the Bible to the War on Terror
}

By LAURA SJObERg AND

CARON E. GENTRY

In almost every culture and every period of history, a she-devil emerges as an example of all that is rotten in the female sex. This Medusa draws together the many forms of female perversion: a woman whose sexuality is debauched and foul, pornographic and bisexual; a woman who knows none of the fine and noble instincts when it comes to men and children; a woman who lies and deceives, manipulates and corrupts. A woman who is clever and powerful. This is a woman who is far deadlier than the male, in fact not a woman at all. ${ }^{1}$

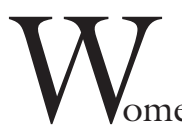
in global politics. When they do, however, their actions are portrayed to the public in stories that emphasize their singularity and deny their agency in their own violence. ${ }^{2}$ Specifically, in news stories and academic work, women engaged in political violence are often depicted as sexual deviants, emphasizing the sexual nature of their dress, mannerisms, and behavior. One researcher even explains women's 'erotomania' as 'the primary reason' why women become terrorists. ${ }^{3}$ In accounts of Bernardine Dohrn, a female leader of the United States' Weather Underground, references to her miniskirts, high boots, and breasts are as frequent as descriptions of her terrorist acts. ${ }^{4}$ The IRA's Maureen O'Hara is described as having 'relied upon her outstanding figure, red hair, and outstandingly pretty face to lure British soldiers to overdrink, overreach, then die slowly and horribly'. ${ }^{5}$ Descriptions of women's non-terrorist violence are also 
often dependent on sexual language. For example, stories about the women implicated in the prisoner abuse at Abu Ghraib emphasize their sexual dependence. ${ }^{6}$

The prominence of sexual language in descriptions of women's violence and terrorism serves to undermine women's agency in their violence. Sexualized stories of violent women can be characterized as 'whore' narratives, which reduce women to their sexuality and obscure investigation of women's actual motives. This article explores the empirical employment of the whore narratives in depictions of women's violence as well as their implications for the study of global politics.

Before proceeding, a quick note on what this article is and is not seems appropriate. The article accepts the empirical reality that men perpetrate the vast majority of violence in global politics. It further acknowledges the 'role of phallocentric ideology and a constructed hegemonic masculinity on the choice made by men to perpetrate violence against women and children'. ${ }^{7}$ It is not arguing that women are violent in a way that makes their violence somehow equivalent to men's. Instead, it argues that, when women are violent, both political and academic reactions stereotype violent women as sexually deviant, robbing them of agency and betraying a larger problem with our understandings of women's roles in politics and international relations. ${ }^{8}$

As such, this article begins by presenting the puzzle of the perceived singularity of women's violence: why is women's violence seen differently than men's? Specifically, why is it that each woman's violence is portrayed as singular and aberrant? The article then explores the sexualization of women's violence as a trend throughout history. Next, it details two strands of the whore narrative frequently employed in the 'war on terror': that of violent women's sexual obsession, and that of violent women's sexual dysfunction. It concludes by arguing that the whore narrative has important implications for the study of global politics, revealing new complexities for global gender inequality and suggesting a new approach to the study of individuals in international relations.

\section{THE DOUBLE TRANSGRESSION OF WOMEN'S VIOLENCE}

Scholars of gender and international relations have identified a paradox of women's integration into global politics: women participate more in areas traditionally reserved for men, but stereotypes about what women should and should not be doing are not disappearing at the same pace. 9 Instead, women's integration into global politics has sacrificed as little white male privilege as possible, and the process has paid little attention to the discursive and performative elements of gender subordination (such as stereotypical narratives). 10

Some scholars herald women's participation in political and criminal violence as proof of gender equality. ${ }^{11}$ At first, this appears to be a logical inference: certainly, violence is one of the last domains of male hegemony. Still, looking at how violent women are portrayed shows that a subtler gender subordination has replaced the outright exclusion of women. Women's participation in 'the same' violence men participate in does not by itself mean they have a gender-equal or gender-neutral role in global politics. ${ }^{12}$ First, the relatively small percentage of women who commit war crimes and terrorism receive a disproportionate amount of media attention. ${ }^{13}$ Women who commit violence are often identified not as terrorists or war criminals, but as women terrorists and women war criminals.

The gendered nature of these portrayals betrays an assumption that women's violence is different and more deviant than men's. Studying women's crimes in the United States, Carol Smart recognized that girls with a criminal record are three times 
more likely to be recommended for institutionalization than boys, because girls' crimes were viewed as sexually deviant. ${ }^{14}$ Smart found that many in the criminal justice system viewed female deviancy as due to a 'much deeper pathology than deviancy by a male'. ${ }^{15}$ These observations translate to the realm of global politics. Indeed, Helena Kennedy finds that female terrorists, such as women in the Weather Underground and the Baader-Meinhof Gang, 'have all provoked more interest and speculation than their male comrades'.16 This interest, however, has little to do with female terrorists' politics. Instead, it betrays a fascination with women terrorists' 'sexual liberation', which sparks the interest of 'their male voyeur'. 17

Many characterizations of violent women link sexual deviance and engagement in violence. In these stories, women are not terrorists and violent criminals but sexually disturbed - or, worse, sexual victims. An unhealthily strong sexual drive or sexual deviance and dependence are seen as root causes of female violence. Given the link between sex and women's violence, a woman is not responsible for her violent actions because she is compelled to them by a combination of sexual instinct and victimization. ${ }^{18} \mathrm{~A}$ woman who can decide to commit a violent crime defies the stereotype of female helplessness and peacefulness. ${ }^{19}$ Instead of acknowledging the falseness of the underlying stereotype, public and publicized stories emphasize the singularity of violent women through sexual depictions. ${ }^{20}$

The reality is that women who commit violence interrupt gender stereotypes. Instead of requiring protection, they are the people from whom others should be protected. $^{21}$ The reality of women's violence, however, is buried under the language of sex in stories about them. This obfuscation occurs because stories of women's agency in violence would interrupt dominant discourses about women's roles generally and about women's relationships to violence specifically. This is where the 'double transgression' of women's violence becomes clear: a violent woman has committed two crimes: her violence, and defying gender stereotypes that deem her incapable of that violence. $^{22}$ As such, acknowledging that women might choose to engage in violence would change both the way we see women and the way we see global politics. Therefore, though women's violence receives a disproportionate amount of media attention, violent women's stories are marginalized within whore narratives, couched in terms that deny women's agency. These sexual descriptions of women's violence have been a feature in historical portrayals of women's violence.

\section{THE HISTORIC SEXUALIZATION OF WOMEN'S VIOLENCE}

Throughout history, women's involvement with war and violence has challenged the stability of the 'gender hierarchy', creating fears that 'society was on the brink of disaster'. ${ }^{23}$ These fears have been reflected in the sexualization of women's violence across time and culture. By 'sexualization' we mean discourses which attract attention to the sexual dimensions of women and/or their violence, and away from other elements.

The sexualization of women's violence is evident in Bible stories and Greek mythology. The Greeks constructed the myths of the terrible Gorgons, which associate women's violence and sexual hedonism, to demonstrate the consequences of women's deviance from traditional gender roles. ${ }^{24}$ The Gorgons' violence revolved around sexuality. The Gorgons were three sisters, the most infamous of whom was Medusa. The creation of the Gorgons' monstrousness - wings, and hair of living snakes - was said to be a curse cast by Athena on the once-beautiful Medusa after she was raped 
in Athena's temple by Poseidon. ${ }^{25}$ Thus, in some accounts, it is only Medusa who has snakes for hair. The sexuality that factored in the creation of the Gorgons was also present in their violent capacities. The special power of the Gorgons was their ability to turn men to stone if those men gazed upon their monstrous beauty. ${ }^{26}$ The message of these myths ties women's violence to sex, and implies that both violent and sexual deviations from prescribed gender roles will 'damage all of civilization'. ${ }^{27}$

Greek mythology is not the only place where sex and women's violence are related. The Bible story of Jezebel shows some similar elements. Jezebel lived at a time when Judaism was gaining support in Israel, causing political conflict between traditional polytheists and Hebrew monotheists. ${ }^{28}$ As queen, Jezebel killed the monotheist Hebrews and their prophets, along with anyone who stood in the way of her husband's power. ${ }^{29}$ In the Old and New Testaments, Jezebel is characterized as 'selling herself' to idols and false gods and is thus a 'whore'. ${ }^{30}$ This language of whoredom is magnified in modern accounts, where explicit sexual references are added. Jezebel has been characterized as the 'mother of harlots and abominations of the earth'. ${ }^{31}$ She is the subject of country songs about sexual unfaithfulness and internet pornography about seduction. ${ }^{32}$ When one enters 'Jezebel' into a Google search, which is fast becoming the pace of American culture, a bizarre mix of biblical and lingerie websites are listed. Jezebel's evil and violence are sexualized, setting a precedent for modern stories that depict violent women as whores.

The trend of sexualizing women's violence can be spotted in early modern history as well. Machiavelli assumed that 'all women within an army were prostitutes, who pursued "those vile avocations which commonly make soldiers idle and seditious". ${ }^{33}$ In this passage, Machiavelli ties women's involvement in militarized force to sexual behavior and sexual deviancy. In The Art of War, Machiavelli goes further, tying not just women's violence but all violence to female sexuality. He explains:

Caution; for fortune is a woman, and if you wish to master her, you must strike and beat her, and you will see that she allows herself to be more easily vanquished by the rash and violent than by those who proceed more slowly and coldly. And therefore, as a woman, she favors youth more than age, for youth is less cautious and more energetic, and commands fortune with greater audacity. 34

Machiavelli's association of female sexuality and chaotic violence was similar to other early modern interpretations. Between 1500 and 1650, women were active and frequent participants in European wars 'as spies, foragers, artillery personnel, or soldiers'. 35 Because women's participation in military violence defied gender stereotypes, women who wanted to participate would frequently dress as men. ${ }^{36}$ Those who were not fighters served essential logistical functions, such as setting up camp, preparing food, nursing soldiers, and managing the transport of necessary equipment. 37 Often, military leaders saw this involvement as threatening and unwanted. 38 Thus, in order to 'limit [women's] empowerment' they were 'present $[\mathrm{ed}]$... as dangerous sexual predators'.39 Women engaged in military violence or logistical support were recast as sexually deviant and it is from this that 'camp follower' became equated with 'whore'. 40

This identification of women in militaries with prostitution did not end in the seventeenth century. Women involved in the armed services during World War II were treated in a similar manner. In wartime British society, women in the military dressed like men (in their uniforms). Some 
people believed that this would lead to women acting like men as well.41 It was feared that the freedom women were given through their involvement in the Auxiliary Territorial Service (ATS), the Women's Auxiliary Air Force (WAAF), and the Women's Royal Naval Service (WRNS) would automatically lead to sexual im-propriety. 42 Women soldiers were characterized as unable to control their own behavior, and likely to become sexual playthings for the male officers. ${ }^{43}$

With the rise of modern terrorism in the late 1960s, and the involvement of women in Marxist-Leninist revolutionary groups, the trend of equating women's involvement in violence with sexuality continued. As mentioned above, in the United States, Dohrn and other Weather Underground members' sexuality was highlighted in media accounts and academic studies. 44 Outside the United States, one of the most flagrant examples of sexualization of women's violence is the treatment of Leila Khaled, a Palestinian woman and long-time member of the Popular Front for the Liberation of Palestine, who captured the world's attention when she hijacked two planes in 1969 and 1970.45 She was frequently depicted in a sexual light and was appropriated as the basis for the bikini- and loin-cloth-clad character, Leela, from $\mathrm{Dr}$ Who. 46

The trend to sexualize and minimize women's political violence is an ancient and ongoing trend. Women's role in global politics becomes fetishized by this equation of political activism and violence to sexual acts and objectification. Through sexual language, women's agency in their own violence is distorted and perverted and femaleness more generally is debased. This trend continues in the war on terror, where a cultural dimension of the sexual discourse around women's violence is also obvious.
RACIALIZED WHORES:

WOMEN'S VIOLENCE AND CULTURE CLASH IN THE WAR ON TERROR

This long trend of the sexualization of women's violence meets a long trend of sexual discourse in international relations: one that extends from the Cold War to the war on terror.47 This discourse has acquired a culture-based, or Orientalist, dimension in the advent of the war on terror. Islamists often resort to the characterization of Western women as whores in order to demonstrate the superiority of their moral frameworks; in return, Western commentators often emphasize the dependence and lack of choice that women experience in conservative Islamic societies. ${ }^{48}$ Sexual discourses about women's violence reflect these cultural tensions.

In the war on terror, the 'whore' narrative can be seen as divided into two categories: erotomania and erotic dysfunction. In the erotomania story, a violent woman commits violence because she is sex-crazed or in a sexual relationship with a male terrorist. This erotomania is often blamed on women's need for attention because they were neglected by their fathers when they were young. 49 According to Robin Morgan, a female terrorist forgoes her womanhood, 'her reality', and buys into patriarchy - committing violence because she is a sexual slave and victim, rather than because she chooses to do so. ${ }^{50}$ A study performed for the United States' government distinguishes rational motivation from erotic motivation in women's terrorism, but not in men's. ${ }^{51}$ In this story, a woman's reasons for participating are both vapid and frightening at the same time vapid because she is driven by sex and not thought, 52 and frightening because women are easily suggestible. Women characterized as erotomaniacs are motivated by their overwhelming perversion. According to this story, women live for or act from sex, while normal women have a discreet and 
controlled sex drive, if they have any at all. This sexual deviance explains the deviance of their violence: erotomania underlies and enables women's violence.

While the erotomania story characterizes women as obsessed with and dependent on sex with men, the erotic dysfunction narrative emphasizes women's unwillingness or perceived inability to please men. In this story, women's violence is blamed on irregularities in their sex lives: their inability to find a husband, 53 their failure to have children, 54 or their homosexuality. 55 Women, unable or unwilling to please men, become emotionally disturbed and translate this emotional trouble into violence. The implication of the erotic dysfunction narrative is that women who commit violence do so because there is something wrong with them that stops them from fulfilling their (normal) biological destiny of becoming wives and mothers.

Both the erotomania and sexual dysfunction strands of the whore narrative are employed in the war on terror. Their employment shows not only assumptions about women, gender, and femininity, but also about cultural and political identity.

\section{AdDICTED TO SEX (AND KILLING): THE WAR ON TERROR AND THE VIOLENT WOMAN}

The erotomania narrative is evident in the war on terror; sexuality is the key factor in many media and scholarly characterizations of women actors. The erotomania story featured in coverage of American women involved in the prisoner abuse at $\mathrm{Abu}$ Ghraib, as well as in accounts of women involved in the terrorist groups that the United States identifies as enemies.

\section{ALL-AMERICAN WHORES}

Megan Ambuhl, Lynndie England, and Sabrina Harman were three of the seven military police officers involved in the prison sex-abuse scandal. Along with men, these women ordered, carried out and performed shockingly sexual acts, such as the molestation of a corpse, photographic documentation of molestation, forced masturbation, forced homosexual acts, and sodomy. ${ }^{56}$ Stories characterizing the women as perverts explained their violence through deviant sexuality, and failed to explore any other motivation for their actions. 57 As a result, the women received an inordinate amount of attention on internet pornography sites, where their abuse fueled entertainment and not dismay. Within a month of the scandal breaking, over 200,000 porn sites featured re-enactments of the Abu Ghraib abuse, and these sites received a total of three hundred million visitors.

The three women have been primarily portrayed as depraved and hedonistic. Scholarly journals have portrayed the women's violence as sadism, 58 masochistic dominatrix games, 59 bestiality, 60 and nymphomania.61 Tales of the women's sexuality formed the core of discourses about their actions. For example, Lynndie England had a child with a man involved in the scandal, Charles Graner, while Megan Ambuhl married him. ${ }^{62}$ These apparently sordid aspects of the women's private lives are a feature of most public stories that focus on the depraved sexuality of these women and how their erotomania allowed for the abuse at Abu Ghraib. Such a portrayal turns the women abusers into sexual objects, not criminals; erotomaniacs, not women.

There is an element of culture clash in the portrayal of the women implicated in the Abu Ghraib prison abuse. ${ }^{63}$ The whore narratives around these women emphasize the titillating aspect of the white women's power over their non-Western, Arab male prisoners. ${ }^{64}$ The stories of these women describe them as white American whores who are constantly screwed by white men 65 and screw Arab men, 66 creating a chain of 
sexual power that feminizes Arab men's masculinity. ${ }^{67}$ American women forcing themselves on Muslim Iraqi men reenvisions the 'clash of civilizations' on a very personal level. 68 The sexualized story of Abu Ghraib sends the message that Iraqi/Islamic men can and should be humiliated, even by American's 'weaker' sex. This humiliation is compounded by the larger discursive conflict about women's sexuality, mentioned above, between the United States and certain Islamic societies. Specifically, radical Islamic rhetoric often criticizes Western women's free sexuality. As such, the sexual abuse of men by Western white women is an ultimate torture and humiliation for a radical Islamic terrorist specifically, and, by a culturebased extension of that story, for Islamic men generally. From an American perspective, this abuse can be seen as an extreme expression of power. From the perspective of these women's victims, sex-based stories of women abusers prove that American women are as sexually uncontrolled as Al Qaeda claims. As such, the sexual discourse about women's violence and the Orientalist ${ }^{69}$ discourses about Islamic society meet in this example of the erotomania narrative.

\section{SEX AND THE FEMALE TERRORIST:} PORTRAYALS IN THE WAR ON TERROR

American women alleged to be war criminals are not the only violent women subject to the erotomania narrative in the war on terror; there is a fascinating flip-side to this sexualized and racialized discourse. While women's involvement in terrorism is not new, the novelty of women involved in selfmartyrdom in the Palestinian, Chechen, and Al Qaeda conflicts in the last decade has attracted substantial media and scholarly attention. ${ }^{70}$ Indeed, whilst other stories concerning women's motivation exist, ${ }^{71}$ the whore narrative is prominent in 'explaining' these women's choice of violence.
Since 27 January 2002, there have been ten female Palestinian self-martyrs. The first, Wafa Idris, was a divorced Red Crescent worker from the West Bank. Some stories point to her divorced status, 'vivacious' personality, and Westernized look (make-up and dress) to argue that her 'blatant' sexuality is what led Idris to become a martyr. ${ }^{72}$ While this may not seem like a strong indictment, in a traditional culture such as that of the Palestinian Territories, words like these condemn Idris to harlotry. Indeed, the seventh 'successful' female Palestinian martyr (for Hamas), Reem Al-Riyashi, allegedly acted because she was atoning for her supposed adultery. ${ }^{73}$ A sexual motivation was also attributed to a would-be female suicide bomber in a story that described her rejoicing that, should she complete her mission, she would become the 'head virgin' when virgins were presented to successful male suicide bombers in heaven. ${ }^{74}$

The sexual obsession strand of the whore narrative is also prominent in American portrayals of $\mathrm{Al}$ Qaeda female suicide bombers. In 2006, a fake cover for Playboy with the headline, 'Women of Al Qaeda' was released on the internet. ${ }^{75}$ The cover featured the image of a woman in a bikini, posing seductively, with her head covered by the top of a burka. ${ }^{76}$ The message was clear: there is a relationship between sex and terror, and Al Qaeda female terrorists are at that nexus of mystery, sexuality, and death.

Similar imagery is a feature of accounts of Chechen women self-martyrs. There is a history of cultural conflict between Russia and Chechnya, often described in derogatory terms. ${ }^{77}$ This use of degrading rhetoric extends to the women, especially as the epithet 'Black Widow' is commonly used to refer to Chechen female self-martyrs. While 'Black Widow' is commonly used to denote a woman who becomes a suicide bomber to avenge a male relative's death, typically her 
husband, a well-represented narrative about the sale of women's bodies to become fodder exists. Within this, the women's actions are also eroticized because of their perceived 'exotic' nature. ${ }^{78}$

As Christopher Dickey portrays them, 'Chechen women [bombers] are as much about tawdry victimization as battlefield heroics' ${ }^{79}$ Chechen female suicide martyrs are often depicted as having been forcefully sold by their families to the Chechen revolutionary forces. 80 One reporter says that the women are 'in a situation not of their own making' and are 'little more than slaves' to the men who control them. ${ }^{81}$ Thus the women are 'prostituted' to the Chechen cause with seemingly little choice in the matter and little control over their future. The stories of the Black Widows as prostitutes even contain a 'madam'. The media report that all the Moscow female suicide martyrs have a female handler known as 'Black Fatima', 82 who has been seen wearing something fit for a Bond villainess - sunglasses, fur coats, and dyedblonde hair. 83 She is said to drug the women's morning orange juice before sending them out on their missions. She is also thought to be the mastermind behind the 2003 Moscow suicide bombing campaign. ${ }^{84}$ In these characterizations, Black Fatima, cool and mysterious, was the one in control - she determined the women's fates and she sent them on their assignations. The madam makes the decisions, not the women, who are portrayed as helpless and innocent even as they martyr themselves.

While the stories of Western women's erotomania portray them as sexual (if not violent) actors, the erotomania tales about the United States' enemies in the war on terror depict them as passive victims of sexual urges assigned to them. This is an unfortunate subjugation that perpetuates, both by alluding to it in the rationale and by contributing to it, the idea that nonWestern women, especially Islamic women, are controlled by men (or madams) and culture and are incapable of agency in politics or violence. ${ }^{85}$

Thus women's violence on both 'sides' of the war on terror is sexualized, and the sexual descriptions bear markers of cultural clash. For the women involved in $\mathrm{Abu}$ Ghraib, the narratives surrounding their violence not only demean the women, but ultimately demean the Iraqi men. The subtext behind women's suicide terrorism in the Palestinian, Al Qaeda, and Chechen conflicts dismiss the women's violence by sexualizing it and adding racial dimensions as ways of limiting women's agency within their radical Islamic context.

\section{SEXUAL 'DYSFUNCTION' \\ AND WOMEN'S VIOLENCE}

While the sexual obsession stories discussed above explain women's violence by their insatiable and uncontrollable need to have sex with men, the sexual dysfunction narratives explain women's violence as related to their inability (or unwillingness) to perform their basic function in life - providing men with sexual pleasure.

An early example of the sexual dysfunction narrative comes from the Amazons, the women warriors of Greek mythology. The Amazons represented the chaos that comes with the (perceived) sexual dysfunction of not needing men for anything more than non-monogamous sex. Amazonian culture was portrayed as very masculine, without a need to include men in their culture. Amazon women were 'not gentle foes' 86 and carried shields, battleaxes, swords, bows, and war spears. ${ }^{87}$ The Amazons' masculinity, though, was not to be honored, but criticized. They were described as physically damaged, 88 sexually hedonistic, ${ }^{89}$ and unnatural. 90 Women who either could not or refused to please men were equated with danger and violence. The Amazons' status as warriors is problematic, but it is compounded by their choice 
to reject the male-dominated lifestyle and create their own, where men are extraneous.

This characterization of violent women as sexually deviant has a prominent place in the history of accounts of women's violence. As Gilbert explains, 'perhaps one of the most deeply held myths about violent women involves lesbianism. If women exhibit violent tendencies, they are not women but rather masculinized.'91 In the sexual dysfunction narrative, women's destiny directly relates to their ability to please men: to serve as a 'good wife', bear children, and mother the children that they have borne. Many stories of violent women discuss their violence in terms of their inability to fulfill that biological destiny, characterizing violent women as somehow sexually less than 'real' or 'regular' women. These stories, which we have grouped as 'sexual dysfunction' narratives, explain violent women as sexually deviant: either as lesbians, as infertile, or as sexually failing their men in some other way.

The language of sexual dysfunction has been applied to women serving in militaries as a way to explain away their defiance of traditional gender roles. As Leisa Meyer explains, 'servicewomen continue to grapple with the sexual images of dyke and whore framing their participation'.92 Women who commit violence are more likely to experience the wrath of these stereotypical understandings. Mason applies this understanding to media characterizations of the women implicated in the abuse at Abu Ghraib:

This 'mannish misfit' stereotype is of course the flipside of the innocuous hillbilly gal represented by images of Jessica Lynch. Countless other commentators have noted the dichotomous way that Lynndie England was represented as a whore while Jessica Lynch was represented as an angel ... If Jessica Lynch was the female Davy Crockett, Lynndie was the female version of the hillbilly rapist. 93
The identification of violent women as 'mannish misfits' judges that there is something wrong with the femininity of those women - that they are not really women at all but some sexually deviant and perverse beings from whom violence is to be expected, even though real women are not violent. This rhetoric resonates through stories of other women's violence in the war on terror.

\section{SHE MUST BE A DYKE:}

\section{JANIS KARPINSKI AND ABU GHRAIB}

In June 2003, Janis Karpinski, an army reserve general, was appointed as the head of 16 United States military prisons in Iraq. ${ }^{94}$ Karpinski and her reservists were trained as military police, charged with keeping order in areas where the conflict had subsided. 95 Military prisons were a new charge, both for Karpinski and for the soldiers she commanded. Karpinski was the only female commander in the war zone, and had served as an operations and intelligence officer with the Special Forces and in the 1991 Gulf War. ${ }^{96}$

When Karpinski was appointed, her womanhood was the subject of a number of newspaper articles. Stories portrayed her as a stereotypical woman, who was 'caring' and 'loves her soldiers', functioning more as a schoolteacher than a soldier. ${ }^{97}$ Only six months later, her soldiers were accused of pouring phosphoric liquid on detainees, beating them with a broom, and sodomizing detainees with chemical lights and broomsticks. ${ }^{98}$ Karpinski maintains that she was unaware of the abuse that was occurring under her command, and, in our interview, characterized herself as a convenient scapegoat in a mismanaged investigation. ${ }^{99}$

In the media, the great majority of stories have accepted Karpinski's claim that she was unaware of the abuse at Abu Ghraib while it occurred.100 Those who have questioned her innocence, though, have done so in very gendered terms. These 
narratives characterize Karpinski as tough, masculine, and even inhuman. A Google search turns up more than a dozen results in the top 50 questioning Karpinski's sexual preference. More specifically, these blogs, newspapers, and websites call her a 'dyke' or a 'bull dyke'.

There is no evidence that Janis Karpinski is, was, or has been attracted to women. 101 Read closely, however, these news stories do not dispute that. Those stories that use profane terms for lesbianism are not concerned with whether or not Karpinski sleeps with women. Instead, they are a metaphorical association which implies that Karpinski is somehow less of a woman: less pure and therefore less female because she was involved in heinous violence. The depiction of Karpinski as a dyke because of her (alleged) involvement with prisoner abuse at Abu Ghraib defines her in opposition to 'real women' who are incapable of that sort of violence. ${ }^{102}$ In this story, the ability to please men is key to womanhood. Lesbians are lesbians because they are unable to please men. This sexual dysfunction drives them to violence. 'Real women', on the other hand, can please their men, and have no need to deviate from traditional gender roles. Karpinski is alleged to have deviated from traditional gender roles, so she must be sexually dysfunctional.

This heteronormative discourse relates sexual deviance to criminality and criminality to sexual deviance. Certainly, reactions proclaiming Karpinski's innocence because of her gender would be seen as entrenching gender subordination. Also, reactions that declare Karpinski to be less than a 'real woman' by blaming her actions on sexual perversion maintain gender subordination by reifying an image of 'real women' as by definition pure and basically good. This story of Karpinski's sexual dysfunction has the dual result of reducing her to sexuality and excluding her from womanhood. It also affects women more broadly by pigeonholing them into a purist category that denies their ability to act or be acted upon in a way that does not exude virginity and innocence.

\section{WOMEN DENIED: FEMALE TERRORISTS' FICTIONALIZED SEXUAL DESPERATION}

The implication of the sexual dysfunction story that violent women are, as a group, not women because their sexual perversions destroy the purity that stops real women from being able to choose to commit proscribed violence is not limited to women in the United States military. It also reverberates in characterizations of female terrorists: there must be something wrong with a woman's femininity in order for her to be able to commit a terrorist act.

In a recent Newsweek article, 'The Women of Al Qaeda', reporter Christopher Dickey seems to indicate that women engage in political violence because of their inadequacy as wives, mothers, or sexual partners. ${ }^{103}$ Dickey portrays women who engage in suicide bombing as having encountered some inadequacy in their path to ideal womanhood. The article describes a woman who engaged in suicide bombing in Iraq as having 'explosives strapped around her womb', implying that her inability to bear children was what she was really blowing up. ${ }^{104}$ By using the term 'womb', the article exploits the role (mother) that women are supposed to play and places her innate womanhood into question by the political action that she has undertaken. ${ }^{105}$ This woman, Myrium Goris, is framed in terms of her failed marriages and inability to have children: so she decided to be a suicide bomber. ${ }^{106}$

This is a different iteration of the sexual dysfunction narrative, but it carries many common themes. Myrium could not have children; Janis Karpinski was a lesbian; both were less qualified to be women on account of their inability or unwillingness to fill the biological destiny of bearing children for 
men. These women, Dickey implies, were so upset by their inability to please men that they lost their sanity and thus found vengeance by killing men, which real women would never do. A violent woman, therefore, is not acting on her womanhood or her humanity, or even a generic defect thereof. Instead, she is acting on the inadequacy of her womanhood. Myrium's story is told as if she was driven not by politics or criminality, but by desperation that could only come from a woman failing at her basic purpose in life: pleasing her man. This sexual inadequacy inspired whorish violence: women who cannot satisfy, kill.

This iteration of the sexual dysfunction narrative of women's violence is implicitly racialized as well. The relationships between women and men in Islamic societies are the subject of much discourse and fantasy in Western societies. Many American public presentations of Islamic women such as Dickey's essentialize Islamic women as subservient to and driven by Islamic men. In the stylized story of Myrium, it is not a (white) Belgian woman who kills herself (and others) over the inability to serve a man; it is an Islamic woman who does so. The subtext of the sexual dysfunction narrative about Myrium is that Islamic women are particularly weak and dependent on men's praise and acceptance. Discourse about the differences between Islamic cultures and those in the United States provides an important context for any political interaction, including narratives of women's violence. The sexual dysfunctionrelated accounts of female suicide bombers imply the (sexual) inferiority of Islamic women and the (racialized) inferiority of those women to cope sanely with that (sexual) inferiority. This is a distinction between the Western version of the sexual dysfunction narrative in Karpinski's story and the Islamic version in Dickey's characterization. The sexually dysfunctional Western woman is violent because she refuses to please men or rebels against her role as one who ought to please men. Islamic women are violent because there is something wrong with them that makes them unable to please men.

\section{IMPLICATIONS FOR THE STUDY OF GLOBAL POLITICS}

The frequency with which sexual language is used to describe women's violence in global politics has several important implications for the field of international relations. The first of those implications is that it provides insight into the complexities of global gender inequality. As mentioned above, women's participation in political and criminal violence looks like gender equality because women are engaging in a realm of global politics that was previously reserved for male participation. Women are doing the things that men do, but are not being treated the same as men. Instead, women's participation in violence in the global arena is sensationalized in a way that perpetuates gender subordination even when women are acting outside traditional gender stereotypes. When women commit terrorist acts or war crimes, the stories told of their crimes are often in terms of sexual deviancy: either obsession or inadequacy.

These stories are a double transgression of gender inequity. First, the whore narratives reduce women to their sexuality, downplaying their agency, much like other cultural manifestations of sexual objectification. Second, they do so while appearing to maintain women's honor (by arguing that violent women are not real women) and/or demonstrate women's equality (through their entry into spheres where their participation was previously barred). This double transgression demonstrates that, even though the spectrum of women's assumed capabilities has widened and its limits have become less obvious, it is not yet limitless. Further, the discursive 
complexity of this sort of gender subordination signifies a sort of inequality that is understudied in international relations: women are doing 'men's tasks' without equality, which reverberates into perpetuating gender stereotypes. The many meanings of inequality (women's exclusion from certain spheres, women's unequal pay/treatment, and discursive manifestations of gender stereotypes) could be studied in the cases of women's integration into military organizations, gender mainstreaming in international organizations and state governments, and women's integration into workplaces from which they were previously excluded.

The whore narrative's employment in global politics also has implications for the ways that we study the individual in global politics. First, when individuals are studied in international relations, they are often elite male individuals. In 2001, Daniel Byman and Kenneth Pollack published an article entitled 'Let Us Now Praise Great Men', heralding the 'Great Men' who shaped the twentieth century. 107 This article argued that it was important to bring the statesmen back into international relations. Byman and Pollack look only at the individual with elite power, and, even then, they focus on the male individual with elite power.

The women in this article, be they suicide bombers or military generals, are actors in global politics. Their status as actors is downplayed by the sexual discourse used to describe their roles. Women who commit political or criminal violence in international relations are an empirical manifestation of Cynthia Enloe's proposition that the personal is international and the international is personal.108 Katharine Moon contends that we need to be 'viewing even the most dispossessed women as "players" in world politics', and instructs that, "without jumping back from two opposite poles of self-agency and victimhood', 'a middle ground must be found'.109 These women's lives are international relations in a number of important ways. First, their choices matter in global politics. The choices that Lynndie England, Sabrina Harman, and Megan Ambuhl made at Abu Ghraib reverberated throughout global politics, as have the choices of the suicide bombers. This is not to say that their choices are entirely independent of their context, but there is no evidence that they are entirely dependent on it either. Instead of seeing sexuality as a structural explanation for women's violence, it is possible to see (broader) structural and agential variables to account for these complex decisions. Second, 'government and media portrayals of women's choices have implications beyond the gender subordination inherent in the ... whore narratives'.110 For example, the media portrayal of Wafa Idris, Reem Al-Riyashi, and Myrium Goris as unhappy women looking for a way out of lives where they could not please or had displeased their man perpetuates subordinating images of Islamic women. It is not just the women being described by the whore narrative who are affected by it; it is women generally, who are essentialized by this treatment of violent women. Finally, if violent women's lives are international relations, an understanding of global politics that neglects them is necessarily incomplete. A number of the women in this article, intentionally or unintentionally, influenced interstate relations. ${ }^{111}$ An understanding of interstate relations that does not account for that influence, then, lacks some explanatory power it could capture.

Insights from feminist international relations theory help to suggest new directions for the study of individual violence in global politics to capture that missing explanatory power that includes women. First, feminist international relations has come to see people as relationally autonomous, rather than either reactively autonomous or dependent.112 In other words, 
people's choices are neither completely independent of context (reactively autonomous) nor entirely involuntary (dependence), but somewhere in between, where they maintain identity independence but decide in a socially constrained world. This means that women's violence can sometimes herald gender emancipation, at other times echo gender subordination, and at yet other times serve both functions at the same time, because no choice is completely independent either of its chooser or its context. Second, feminist international relations theory has created space for the integration of (not only elite, but also marginalized) people into global politics. ${ }^{113}$ This can serve as an interpretive framework for studying violent women as actors, rather than accepting the inherited whore narratives. Third, feminists have repeatedly compared the stories told about men to the stories told about women in global politics, asking where the women are and what their agency is. ${ }^{114}$ Applying those questions to the study of women's violence shows that most portrayals of that violence minimize women's choice in it, while many portrayals of men analyze their motivation as if their actions were rationally chosen. Fourth, feminists have argued that sex matters in international relations. ${ }^{115}$ Studies of the whore narrative can be synthesized with a research program on the sexuality of international relations. Finally, contrary to Barbara Ehrenreich's claim,116 women's violence does not demonstrate the end of the need for feminist scholarship in international relations, but instead elevates the importance of gender lenses looking for increasingly subtle, complex, and disguised ways through which gender inequity permeates international relations.

\section{Notes}

1. Helena Kennedy, Eve Was Framed: Women and British Justice (London: Vintage, 1992), p. 240.

2. Laura Sjoberg and Caron Gentry, Mothers, Monsters, and Whores: Women's Violence in Global Politics (London: Zed Books, 2007).

3. 'The Female Terrorist and her Impact on Policing', Top Security Project No. 2 Part IV Summary and Analysis, 1976, pp. 242-5.

4. Susan Stern, With the Weathermen (Garden City, NY: Doubleday, 1975). See also Peter Collier and David Horowitz, Destructive Generation: Second Thoughts about the Sixties (London: Summit Books, 1990), and Catherine Taylor, “"And Don't Forget to Clean the Fridge”: Women in the Secret Sphere of Terrorism', in Gerard J. DeGroot and Corinna Bird-Peniston (eds), A Soldier and a Woman: Sexual Integration in the Military (Harlow: Pearson Education, 2000), pp. 294-304.

5. Taylor, “'And Don't Forget to Clean the Fridge", p. 300.

6. Laura Sjoberg, Gender, Justice, and the Wars in Iraq (Lanham, MD: Lexington Books, 2006); Laura Sjoberg, 'Agency, Militarized Femininity, and Enemy Others: Observations from the War in Iraq', International Feminist Journal of Politics, 9(1), 2007, pp. 82-101.

7. Lee Fitzroy, 'Violent Women: Questions for Feminist Theory, Practice, and Policy', Critical Social Theory, 21(1), 2004, pp. 7-34.

8. Estella V. Welldon, Mother, Madonna, and Whore: The Idealisation and Denigration of Motherhood (London: Free Association Books, 1988).

9. Cynthia Enloe, Maneuvers: The International Politics of Militarizing Women's Lives (Berkeley: University of California Press, 2000).

10. For a discussion of the emphasis on women as women, see Cynthia Enloe, Bananas, Beaches, and Bases: Making Feminist Sense of International Relations (Berkeley: University of California Press, 1990). For more detail about the performative and discursive elements of gender subordination, see Judith Butler, Bodies that Matter: On the Discursive Limits of Sex (New York: Routledge, 1993). 11. See, e.g., Barbara Ehrenreich, 'What Abu Ghraib Taught Me', Los Angeles Times, 21 May 2004. 12. Cynthia Cockburn, In the Way of Women: Men's Resistance to Sex Equality in Organizations (London: Zed Books, 1991).

13. See Cynthia Enloe, The Morning After: Sexual Politics at the End of the Cold War (Berkeley:

University of California Press, 1993). Enloe argues that, in the beginning of the First Gulf War (when 
the percentage of deployed soldiers who were women went up from less than half of 1 percent in the Vietnam War to 7 percent in that war), there was an outpouring of media attention to female soldiers, far disproportionate to women's actual representation as members of the fighting force. She attributes this to a rise in the salience of femininity: people were interested in women soldiers not as soldiers but as women soldiers, a distinction which, rather than highlighting the gender equalities in an integrated military, demonstrates that even an integrated military can maintain gender stereotypes.

14. Carol Smart, Law, Crime, and Sexuality (London: Sage, 1995).

15. Smart, Law, Crime, and Sexuality, p. 133;

Karen Heimer and Stacy De Coster, 'The Gendering of Violent Delinquency', Criminology, 37(2), 1999, pp. 283.

16. Kennedy, Eve Was Framed, p. 261.

17. Kennedy, Eve Was Framed, p. 262.

18. Robin Morgan, The Demon Lover: The Roots of Terrorism (New York: Washington Square, 1989).

19. Chimene I. Keitner, 'Victim or Vamp? Images of Violent Women in the Criminal Justice System', Columbia Journal of Law and Gender, 11, 2002, p. 75 .

20. Andrea Shapiro, 'Unequal Before the Law: Men, Women, and the Death Penalty', American Journal of Gender, Social Policy, and Law, 8, 2000, p. 427; Keitner, 'Victim or Vamp?', p. 69. 21. Feminists have called this phenomenon the 'protection racket', where men claim to fight wars to protect women when they really put women in danger, using women's innocence as a tool to make war and a fable about war at the same time. See Iris Marion Young, 'The Logic of Masculinist Protection: Reflections on the Current Security State', Signs: Journal of Women in Culture and Society, 29(1), 2003, pp. 1-25; Laura Sjoberg, 'Gendered Realities of the Immunity Principle: Why Gender Analysis Needs Feminism', International Studies Quarterly, 50(4), December 2006, pp. 889-910.

22. Keitner, 'Victim or Vamp?', p. 40.

23. Brian Crim, 'Silent Partners: Women and Warfare in Early Modern Europe', in DeGroot and Bird-Peniston, A Soldier and a Woman, p. 27. 24. Cynthia Enloe, Does Khaki Become You? The Militarization of Women's Lives (London: Pluto Press, 1983), pp. 117-18.

25. Stephen R. Wilk, Medusa: Solving the Mystery of the Gorgon (New York: Oxford University Press, 2000), pp. 24-5.
26. Edith Hamilton, Mythology: Timeless Tales of Gods and Heroes (New York: Penguin Books, 1940), p. 143.

27. Richard J. Lane and Jay Wurts, In Search of the Woman Warrior: Role Models for Modern Women (Boston: Element, 1998), p. 51.

28. Life Applications Bible (Grand Rapids, MI: Zondervan Publishing House, 1991), p. 591.

29. Life Applications Bible, p. 591.

30. 2 Kings 9:22 and Revelation 2:20.

31. Jay Atkinson, 'Jezebel', Latter Rain Page, available at: http://latter-rain.com,eschae/jezebel.htm (accessed 28 June 2006).

32. See Chely Wright (artist), 'Jezebel', a song about a woman trying to steal another woman's husband. A list of relevant internet sites will not be published, but is available by contacting the authors.

33. Crim, 'Silent Partners', p. 28; Machiavelli, The Art of War (New York: Collectors Books, 2004), p. 374.

34. Machiavelli, Art of War, p. 128.

35. Crim, 'Silent Partners', p. 27.

36. Crim, 'Silent Partners', p. 27.

37. Crim, 'Silent Partners', p. 27; Scott N.

Hendrix, 'In the Army: Women, Camp Followers, and the Gender Roles in the British Army in the French and Indian Wars, 1775-1776', in DeGroot and Bird-Peniston, A Soldier and a Woman, p. 34.

38. Crim, 'Silent Partners', p. 28.

39. Gerard J. DeGroot, 'Arms and the Woman', in DeGroot and Bird-Peniston, A Soldier and a Woman, p. 16.

40. Hendrix, 'In the Army', p. 36.

41. Gerard J. DeGroot, 'Lipstick on her Nipples, Cordite in her Hair: Sex and Romance among British Servicewomen during the Second World War', in DeGroot and Bird-Peniston, A Soldier and a Woman, p. 110.

42. DeGroot, 'Lipstick on her Nipples', p. 101.

43. DeGroot, 'Lipstick on her Nipples', pp. 101 and 103.

44. Stern, With the Weathermen.

45. Leila Khaled, My People Shall Live: The Autobiography of a Revolutionary (London: Hodder and Stoughton, 1973).

46. Katharine Viner, 'I Made the Ring from a Bullet and the Pin of a Hand Grenade', The Guardian, 26 January 2001; Morgan, The Demon Lover; Wikipedia, 'Leela (Dr Who)', available at: http:// en.wikipedia.org/wiki/Leela_\%28Doctor_Who\%2 9 (accessed 1 May 2007).

47. Carol Cohn, 'Sex and Death in the W.orld of Rational Defense Intellectuals', Signs: Journal of 
Women in Culture and Society, 12(4), 1987, pp. 687-718. Sjoberg, Gender, Justice, and the Wars in Iraq, explains that Saddam Hussein and George W. Bush had an argument about which was manlier, with Bush telling Saddam Hussein that 'real men' do not invade smaller countries, and Hussein replying that he would be willing to show Bush what a real man does. Sjoberg and Gentry, Mothers, Monsters, and Whores, includes accounts of sexualized competitive rhetoric between the United States government and $\mathrm{Al}$ Qaeda concerning how women are treated and/or allowed to behave. For a discussion of this competition of masculinity, see Steve Niva, 'Tough and Tender: New World Order Masculinity and the Gulf War', in Marysia Zalewski and Jane Parpart (eds), The 'Man' Question in International Relations (Boulder, CO: Westview Press).

48. For example, a Pew study found 'Western publics, by lopsided margins, do not think of Muslims as "respectful of women." But half or more in four of the five Muslim publics surveyed say the same thing about people in the West.' Pew Global Attitudes Project, 'The Great Divide: How Westerners and Muslims View Each Other', 6 June 2006, available at: http://pewglobal.org/reports/ display. php? ReportID=253 (accessed 13 June 2007). See also Lucinda Marshall, 'Women in Iraq and Afghanistan: U.S. Actions Do Little to Help', Off Our Backs, July/August 2004, available at: http://findarticles.com/p/articles/mi_qa3693/is _200407/ai_n9430139 (accessed 13 June 2007). 49. 'The Female Terrorist', p. 245.

50. Morgan, Demon Lover, pp. 166-8.

51. 'The Female Terrorist', p. 245.

52. Morgan writes that women in the Italian Red Brigades and the West German Red Army Faction were members to gain 'male approval and love' (Demon Lover, pp. 204-5).

53. Shaul Kimhi and Shemuel Even, 'Who are the Palestinian Suicide Bombers?', Terrorism and Political Violence, 16(4), 2004, pp. 815-40. 54. Christopher Dickey, 'Women of Al Qaeda', Newsweek, 4 December 2005, available at: www.msnbc.msn.com/id/10315095/site/ newsweek/ (accessed 5 December 2005), p. 1. 55. Meda Chesney-Lind and Michele Eliason, 'From Invisible to Incorrigible: The Demonization of Marginalized Women and Girls', Crime, Media, and Culture, 2(1), 2006, p. 29.

56. General Taguba's unpublished report concerning the fault for the abuse at Abu Ghraib, available at: www.npr.org/iraq/2004/prison_abuse_report.pdf (accessed 24 November 2007), pp. $1-23$.
57. See, e.g., Tara McKelvey, 'A Soldier's Tale', Marie Claire, 2006, available at: http:// magazines.ivillage.com/marieclaire/mind/ issues/articles/0,,434739_703130,00.html (accessed l January 2007). This story goes into great detail about Lynndie England's sexual exploits as explanation for her participation in the prisoner abuse.

58. Emily Apter, 'On Oneworldness, or Paranoia as a World System', Journal of American Literary History, 18(2), 2006, pp. 365-89.

59. Jan Jagodzinski, 'The Trauma of the Image: Prisoner "Abuse" in Abu Ghraib Prison', Studies in Media and Information Literacy Education, 6(1), 2006, pp. 365-89.

60. Jasbir Puar, 'Mapping US Homonormatives', Gender, Place, and Culture: A Journal of Feminist Geography, 13(1), 2006, pp. 66-88.

61. Pamela Paul, Pornified: How Pornography is Transforming our Lives, our Relationships, and our Families (New York: Times Books, 2005). 62. McKelvey, 'A Soldier's Tale', email correspondence with Megan (Ambuhl) Graner, summer 2006.

63. Sjoberg, 'Agency, Militarized Femininity, and Enemy Others', p. 85.

64. Gender-based violence is sexual violence, such as rape, sodomy, molestation and sexual torture, designed to undermine or manipulate what it means to be a man or a woman in a certain context. Certainly the abuse of the Middle Eastern men by white women is a purposeful use of power to demonstrate a power-over relationship between the US military and the Iraqi prisoners. See Julie A. Mertus, War's Offensive on Women: The Humanitarian Challenge in Bosnia, Kosovo, and Afghanistan (Bloomfield, CT: Kumarian Press, 2000), p. 16.

65. This element of the narrative is obvious in stories about the women's relationships, which feature the sex acts between England and Graner, as well as other descriptions which treat the involved women as sex toys of the involved men. See Sjoberg, 'Agency, Militarized Femininity, and Enemy Others', pp. 89-91.

66. This element of the narrative can be seen in the pictures, where the women soldiers play sexual roles normally considered masculine in relation to male prisoners in positions normally considered feminine.

67. See Niva, 'Tough and Tender', for a detailed description of this sexualized competition. 68. For example, Samuel Huntington, The Clash of Civilizations and the Re-making of World Order (London: Simon and Schuster, 1997). 
69. Edward Said, Orientalism (New York: Pantheon Books, 1978). Said argues that all discourses, especially discourses about 'Eastern' culture coming from the 'West', are inherently ideological. Said argues that this Orientalist discourse creates rather than describes the conflicts between Eastern and Western cultures. 70. Women's involvement in terrorist organizations is not new - from the Russian anarchist group Narodnaya Volya in the late 1800s to the prominent place women held in Marxist-Leninist groups in the 1960s (most of the membership of these groups in the West was split equally between the genders), women's involvement with terrorism may not be well known, but it is not new. Neither are the historical examples of women's engagement with suicide campaigns. Women in Kurdish and Sri Lankan groups have conducted selfmartyrdom bombings for well over a decade. See Martha Crenshaw (ed.), Terrorism in Context (University Park, PA: Pennsylvania State University Press, 1994), and Bruce Hoffman, Inside

Terrorism (New York: Columbia University Press, 2006).

71. Sjoberg and Gentry, Mothers, Monsters, and Whores, features two other narratives: that of motherhood as a motivation to kill, and that of the insanity and monstrousness of violent women. 72. Barbara Victor, An Army of Roses: Inside the World of Palestinian Women Suicide Bombers (New York: Rosdale Press, 2003); Phil Reeves, 'The Paramedic Who Became Another "Martyr" for Palestine', Independent, 31 January 2002. 73. Claudia Brunner, 'Female Suicide Bombers Male Suicide Bombing? Looking for Gender in Reporting the Suicide Bombings of the IsraeliPalestinian Conflict', Global Society, 19(1), 2005, p. 34; 'Female Suicide Bomber Fulfils Grim Wish, Killing 4', Associated Press, 15 January 2004, available at: http://web.lexis-nexis.com/universe (accessed 9 May 2006).

74. A. M. Oliver, 'The Brides of Palestine', Salon.com, 20 July 2006, available at: www.salon.com/mrt/feature/2006/07/20/ suicide_bombers/(accessed l January 2007). 75. Internet Weekly Report, 'The Women of Al Qaeda', available at: www.internetweekly.org/ photo_cartoons/cartoon_women_of_al_qaeda. html (accessed 25 August 2006).

76. Internet Weekly Report.

77. While Chechen women are literally Caucasians, this does not remove their history and circumstances from prejudice and racialized imagery. Since the early 1800s, Chechens have been constructed in Russian culture as the 'Other'.
Chechens are seen as being distinctly non-Russian and as 'wicked' and 'fierce' warriors. Derogatory Russian words for Chechens include cherniye (blacks) or chernozhopy (black arses).

78. V. Groskop, 'Women at the Heart of the Terror Cells', Guardian, 5 September 2004.

79. Dickey, 'Women of Al Qaeda'.

80. N. P. Walsh, 'Sisters in Arms', Guardian, 1 September 2005, p. 6; Luba Vinogradova, 'Deadly Secret of the Black Widows', The Times, 2 October 2003 , p. 4.

81. Vinogradova, 'Deadly Secret', p. 4.

82. M. McDonald, 'Chechnya's Eerie Rebels:

Black Widows', The Gazette (Montreal), 24

October 2003, p. A4; Tom Parfitt, 'Russian

Soldiers Blamed for Civilian Rape in Chechnya',

The Lancet, 363, 17 April 2004, p. 28.

83. Viktor Paukov and Viktor Svistunov, "'Black Widows" Were Just Steps away from Kremlin', Vremya Novostei, 10 December 2003; Parfitt, 'Russian Soldiers Blamed', p. 28.

84. Richard Beeston, 'Black Widow Suicide Bombers Are Extremists' Worst Weapon', The Times, 3 September 2004, p. 4; Parfitt, 'Russian Soldiers Blamed', p. 28.

85. See Valerie Moghadam (ed.), Gender and Nationalism: Women and Politics in Muslim Societies (Helsinki: United Nations University World Institute for Development Economics Research, 1994).

86. Hamilton, Mythology, p. 122.

87 David E. Jones, Women Warriors: A History

(London: Brassey's, 2000), p. 6.

88. Crim, 'Silent Partners', p. 20.

89. Among the many horrors of the Amazons, the Greeks described them as women who treated men as slaves and as expendable. They 'mated randomly' and as such displayed promiscuous behavior (Jones, Women Warriors, p. 6). They did not marry (Jones, Women Warriors, p. 8). The Amazons treated men much like the Greek patriarchal society treated women - as inferior and no better than slaves or children. The Amazons crippled or killed their male children in order to limit their power and keep them as slaves, but raised physically healthy female children (Jones, Women Warriors, p. 6).

90. Lane and Wurts, In Search of the Woman Warrior, pp. 41 and 48.

91. Paula Ruth Gilbert, 'Discourses of Female Violence and Societal Gender Stereotypes', Violence Against Women, 8(11), 2002, pp. 1271-1300; Lynda Hart, Fatal Women: Lesbian Sexuality and the Mark of Aggression (Princeton, NJ: Princeton University Press, 1994). 
92. Leisa D. Meyer, 'Creating GI Jane: The Regulation of Female Sexuality and Sexual Behavior in the Army Corps during World War II', Feminist Studies, 18(3), 1992, pp. 581-601.

93. Carol Mason, 'The Hillbilly Defense:

Culturally Mediating US Terror at Home and Abroad', National Women's Studies Association Journal, 17(3), 2005, pp. 39-63.

94. Janis Karpinski and Steven Strasser, One Woman's Army: The Commanding General of Abu Ghraib Tells her Story (New York: Miramax Books, 2005); Janis Karpinski, personal interview with Laura Sjoberg, 13 October 2006.

95. Karpinski, personal interview.

96. Karpinski, personal interview.

97. Susan Taylor Martin, 'Her Job: Lock up Iraq's Bad Guys', St Petersburg Times, 14 December 2003 , p. A8.

98. This list of allegations is derived from General Taguba's report.

99. Karpinski and Strasser, One Woman's Army; Karpinski, personal interview.

100. There is gender in these stories, as well. Most notably, several stories discuss Karpinski's gender as the reason why she was such a poor leader in not knowing that there was prison abuse occurring under her command (see, for example, Jack Wheeler, 'Take it Like a Man', Washington Times, 21 May 2004).

101. In fact, she has been married for 30 years to a man. When asked about this, in our interview, she told Laura Sjoberg that the military was a tough place for sexual minorities, so this was language that she was used to hearing. She characterized those assertions as baseless and ridiculous, but said that she tried not to let them get to her.

102. Sjoberg and Gentry, Mothers, Monsters and Whores, p. 80.

103. Dickey, 'Women of Al Qaeda', p. 1.

104. Dickey, 'Women of Al Qaeda', p. 2.

105. Dickey, 'Women of Al Qaeda', p. 1.

106. Dickey, 'Women of Al Qaeda', p. 2.

107. Daniel Byman and Kenneth Pollack, 'Let Us

Now Praise Great Men: Bringing the Statesman

Back In', International Security, 25(4), 2001, pp.

107-46.

108. Enloe, Bananas, Beaches, and Bases, p. 196.

109. Katharine Moon, Sex Among Allies:

Militarized Prostitution in U.S.-South Korea

Relations (New York: Columbia University Press, 1997).

110. Sjoberg and Gentry, Mothers, Monsters, and Whores, p. 270.

111. For example, the women who participated in
Abu Ghraib negatively influenced not only the relationship between the United States and the Iraqis it governed at the time, but also between the United States and several other Islamic countries. Palestinian women suicide bombers affected the scale and shape of the Israel-Palestine conflict. 112. Here, reactive autonomy means that people are perceived as able to make choices entirely independently of the choices of others (Christine Sylvester, 'Feminists and Realists on Autonomy and Obligation in International Relations', seminar paper, University of Southern California, Center for International Studies, 1990). Relational autonomy recognizes that humans are interdependent, so their decisions, while not completely unfree, are reliant on each other (Nancy Hirschmann, 'Freedom, Recognition, and Obligations: A Feminist Approach to Political Theory', American Political Science Review, 83(4), 1989, pp. 1217-44.

113. See, for example, Moon, Sex Among Allies; Christine Chin, In Service and Servitude: Foreign Female Domestic Workers and the Malaysian 'Modernity' Project (New York: Columbia University Press, 1998).

114. See J. Ann Tickner, Gender in International Relations: Feminist Perspectives on Achieving Global Security (New York: Columbia University Press, 1992); J. Ann Tickner, Gendering World Politics (New York: Columbia University Press, 2001).

115. In Sex Among Allies, Moon argues that women's prostitution is key to the relationship between the United States and South Korea. In Gender, Justice, and the Wars in Iraq, Sjoberg argues that sexual discourse about penetration was a linchpin of the relationship between the United States and Iraq in the 1990s. In Manly States: Masculinities, International Relations, and Gender Politics (New York: Columbia University Press, 2001), Charlotte Hooper argues that the discourse of sexual competition is a necessary explanatory variable in international relations. These ideas, and this work on the whore narrative, can serve as the foundation for a research program on sex and sexuality in global politics.

116. Ehrenreich, 'What Abu Ghraib Taught Me'.

This article was first published as:

Reduced to bad sex: Narratives of Violent Women from the Bible to the War on Terror, in International Relations (2008) no. 22, vol. 5: 5-24, Sage, kindly granting permission to republishing it here. 